\title{
Contribution of glacier runoff to water resources of La Paz city, Bolivia $\left(16^{\circ} \mathrm{S}\right)$
}

\author{
Alvaro SORUCO, ${ }^{1}$ Christian VINCENT, ${ }^{2}$ Antoine RABATEL, ${ }^{2}$ Bernard FRANCOU, ${ }^{3}$ \\ Emmanuel THIBERT, ${ }^{4,5}$ Jean Emmanuel SICART, ${ }^{3}$ Thomas CONDOM ${ }^{3}$
}

\author{
${ }^{1}$ UMSA, Instituto de Geológicas y del Medio Ambiente, La Paz, Bolivia \\ ${ }^{2}$ Université Grenoble Alpes, CNRS, LGGE (UMR 5183), Grenoble, France \\ ${ }^{3} I R D$, Université Grenoble Alpes, CNRS, G-INP, LTHE (UMR 5564), Grenoble, France \\ ${ }^{4}$ IRSTEA, UR ETGR, Erosion torrentielle neige et avalanches, Saint-Martin-d'Hères, France \\ ${ }^{5}$ Université Grenoble Alpes, Grenoble, France \\ Correspondence: Alvaro Soruco <alvaro.soruco@gmail.com>
}

\begin{abstract}
The supply of glacier water to La Paz city, Bolivia, between 1963 and 2006 was assessed at annual and seasonal timescales based on the mass-balance quantification of 70 glaciers located within the drainage basins of La Paz. Glaciers contributed $\sim 15 \%$ of water resources at an annual scale $(14 \%$ in the wet season, $27 \%$ in the dry season). Uncertainties in our estimation are related to the assumed constant precipitation $(\sim 0.5 \%$ for ice-free areas and up to $6.5 \%$ for glaciated areas), the constant runoff coefficient $(\sim 1 \%)$, the surface areas of the glaciers and catchments $(\sim 5 \%)$ and the mean massbalance uncertainty of the 21 glaciers used to obtain the mass balance of the 70 glaciers $(12 \%$ of the total discharge). Despite the loss of $50 \%$ of the glacierized area during the study period, runoff at La Paz did not change significantly, showing that increase in ice melt rates compensated for reduction in the surface area of the glaciers. In the future, assuming complete disappearance of the glaciers and no change in precipitation, runoff should diminish by $\sim 12 \%$ at an annual scale, $9 \%$ during the wet season and $24 \%$ during the dry season.
\end{abstract}

KEYWORDS: glacier hydrology, glacier mass balance, mountain glaciers, tropical glaciology

\section{INTRODUCTION}

Glacier mass balance is a valuable indicator of climate change over the past century (Stocker and others, 2013). Tropical glaciers are very sensitive and respond rapidly to climate fluctuations, mainly due to their relatively small size (Rabatel and others, 2006, 2013; Soruco and others, 2009a), the strong atmosphere-surface-energy exchanges at low latitudes (Francou and others, 2000), and tropical climate conditions that maintain the lower reaches of glaciers in almost permanent ablation conditions all year round. As a result, small changes in temperature and precipitation strongly impact the glacier mass balance. In a recent review of glaciological surveys in the tropical Andes, Rabatel and others (2013) show that glacier shrinkage has accelerated in recent decades in response to climate change and, in particular, increasing temperatures. In addition to the importance of tropical glaciers as climate indicators at high altitudes in the tropics, it is widely accepted that these glaciers are crucial water resources for high-altitude inhabited areas, especially during the dry season (e.g. Ribstein and others, 1995; Coudrain and others, 2005; Vergara and others, 2007; Kinouchi and others, 2013; Rangecroft and others, 2013). However, only a few studies have focused on the real contribution of glaciers to the water resources of large cities in the Andean region (e.g. Mark and Seltzer, 2003; Vergara and others, 2007; Gascoin and others, 2011; Baraer and others, 2012; Buytaert and De Bièvre, 2012). More specifically, assessing the contribution of glaciers to the supply of water to La Paz and El Alto cities is essential for future water management in Bolivia (Buytaert and De Bièvre, 2012). Indeed, the population of La Paz and El Alto is increasing (2 million inhabitants in 2012), while the surrounding glaciers have lost mass continuously since the late 1970s (Soruco and others, 2009a; Liu and others, 2013; Rabatel and others, 2013), particularly during El Niño events (Wagnon and others, 2001). In addition, general circulation models point to maximum temperature increases at high altitudes in the tropical Andes in the future (Bradley and others, 2006). Vergara and others (2007) estimated the contribution of glaciers to the water resources of La Paz city at $30-40 \%$, but they did not use mass-balance data from glaciers located in the La Paz drainage basin. Decadal changes in glacier volume estimated from differences in digital elevation models (DEMs) (the so-called geodetic method) are recognized as the most accurate way of providing an unbiased estimation of the mean annual mass balance over time (Thibert and Vincent, 2009; Zemp and others, 2013). Mean annual changes in glacier mass computed for 21 glaciers close to La Paz city using the geodetic method were presented in Soruco and others (2009a). This information allows accurate estimation of the contribution of ice melt, which is indispensable for advanced planning, and assessment of the economic cost of future dams to ensure the supply of fresh water to La Paz city.

A long-term glaciological monitoring program in Bolivia started in 1991 on Glaciar Zongo, Glaciar Chacaltaya (which disappeared in 2009) and Glaciar Charquini Sur (since 2002) in the framework of the observatory GLACIOCLIM (les GLAClers, un Observatoire du CLIMat: http://www-lgge.ujfgrenoble.fr/ServiceObs/SiteWebAndes/index.htm) (Francou and others, 1995; Rabatel and others, 2013). The aim of the present study is to assess the contribution of glaciers to water discharge at La Paz city at annual and seasonal scales. To this end, we calculated the different contributions of 


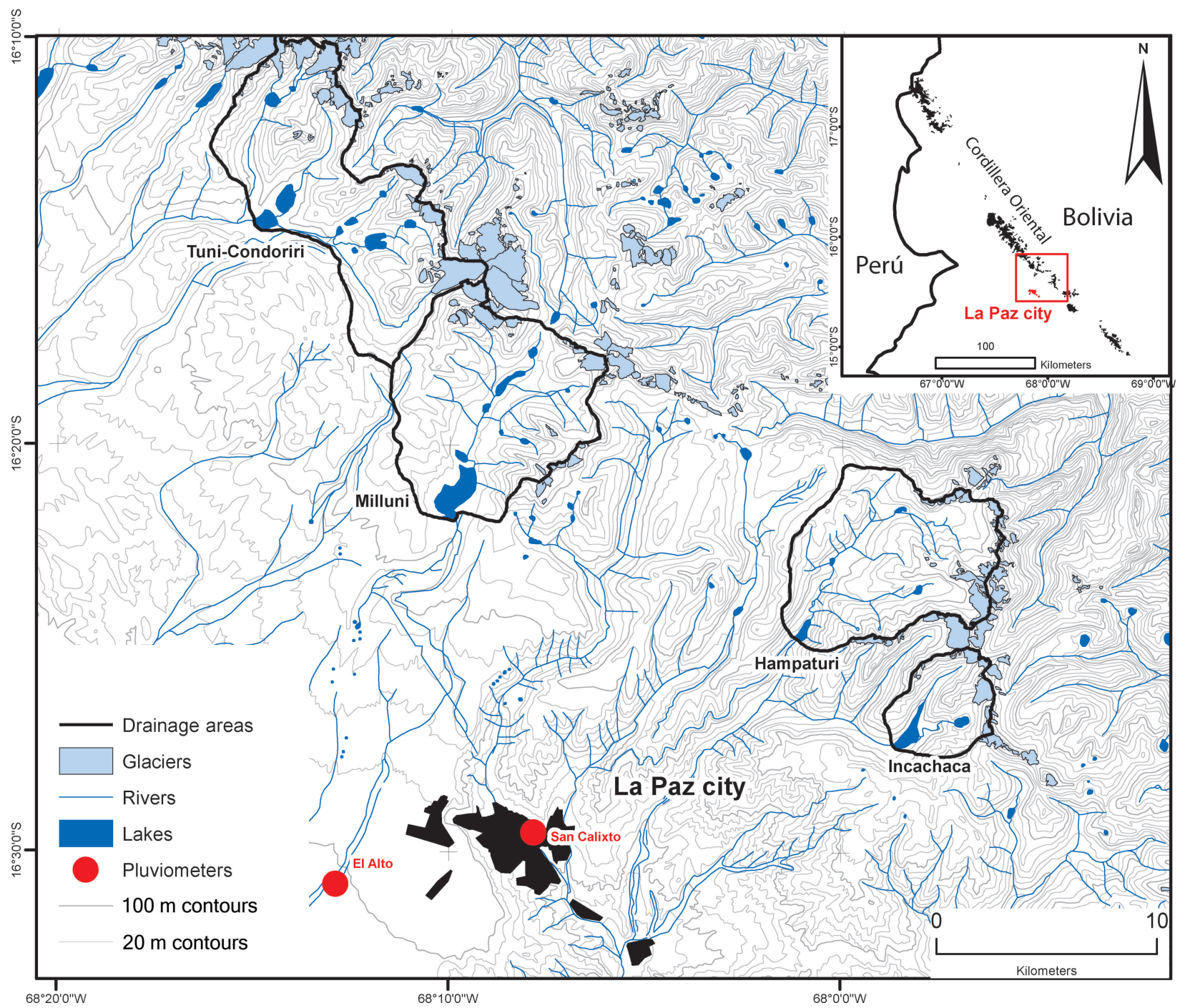

Fig. 1. Map of the study area, showing the La Paz city drainage areas and glaciers in the region. The inset shows the location of the study site in Bolivia.

discharge due to glacier melting and precipitation. We estimate the potential contribution of glaciers to runoff at La Paz and the decrease in runoff after the hypothetical disappearance of all glaciers in the contributing basins.

\section{STUDY AREA AND GENERAL SETTINGS}

La Paz city is located at $16^{\circ} 29^{\prime} \mathrm{S}, 68^{\circ} 08^{\prime} \mathrm{W}$, on the Altiplano plateau between 4000 and 3300 ma.s.l. (Fig. 1). Climate conditions in this area are characterized at an annual scale by low temperature seasonality, contrasting with high precipitation seasonality, with the wet season lasting from October to March and the dry season from April to September. The majority of glaciers in the Bolivian Cordillera Oriental are south-facing (Jordan, 1991). As shown in previous studies (Wagnon and others, 1999; Sicart and others, 2005), the mass balance of these glaciers is mainly driven by surface albedo and radiation, which, in turn, are controlled by solid precipitation and cloud cover. The hydrological year runs from September to August (Ribstein and others, 1995). The October-December period is characterized by strong ice melt over the ablation zone, mainly due to reduced snow cover and strong solar radiation close to the austral summer solstice (Wagnon and others, 1999; Rabatel and others, 2012). The JanuaryMarch period is the height of the wet season and corresponds to the glaciers' accumulation period. In this season, ablation is nevertheless high in the lower part of the glaciers mainly due to snowmelt, enhanced by atmospheric longwave radiation from the cloud cover (Sicart and others, 2005; Rabatel and others, 2012). May-August is the dry season, when the accumulation rate is very low. During this period, sublimation is the main ablation process (Wagnon and others, 1999; Sicart and others, 2005).

The La Paz city water system mainly comprises four drainage areas (Fig. 1): from north to south, Tuni-Condoriri $\left(78 \mathrm{~km}^{2}\right)$, Milluni $\left(71 \mathrm{~km}^{2}\right)$, Hampaturi $\left(60 \mathrm{~km}^{2}\right)$ and Incachaca $\left(18 \mathrm{~km}^{2}\right)$. The water is collected in three drinkingwater treatment plants: El Alto station collects water from the Tuni-Condoriri area, Achachicala station collects water from the Milluni area, and Pampahasi station collects water from the Hampaturi and Incachaca areas. According to the 1975 aerial photographs used for the Bolivian glacier inventory (Jordan, 1991), Tuni-Condoriri, Milluni, Hampaturi and Incachaca contained respectively 30 glaciers $\left(9.1 \mathrm{~km}^{2}\right), 13$ glaciers $\left(3.6 \mathrm{~km}^{2}\right), 18$ glaciers $\left(3.2 \mathrm{~km}^{2}\right)$ and 9 glaciers $\left(1.8 \mathrm{~km}^{2}\right)$, corresponding respectively to $12 \%, 5 \%$, $5 \%$ and $10 \%$ of the glacierized area of each catchment area. 
Tropical glaciers in South America have been retreating since 1975 (Rabatel and others, 2013). Glaciers located below $5400 \mathrm{ma}$ a.s.l. show an average annual loss of $\sim 1.2 \mathrm{~m}$ w.e. $\mathrm{a}^{-1}$ over the past three decades, which is twice that of glaciers whose accumulation area is located above 5400 m a.s.l. (Rabatel and others, 2013). Between 1975 and 2006, the glacierized areas of Tuni-Condoriri and Milluni decreased by $\sim 50 \%$ (Soruco and others, 2009a).

\section{METHODOLOGY AND DATA}

The total annual discharge of high-altitude catchment areas $\left(D_{\mathrm{CA}} ; \mathrm{m}^{3} \mathrm{a}^{-1}\right)$, which includes all the La Paz drainage basins, is the sum of the annual ice- and snowmelt discharge produced by the glacierized area $\left(D_{\mathrm{GA}} ; \mathrm{m}^{3} \mathrm{a}^{-1}\right)$ and the annual discharge from ice-free areas $\left(D_{\mathrm{FOIA}} ; \mathrm{m}^{3} \mathrm{a}^{-1}\right)$.

Snow and ice melt at the glacier surface $\left(M_{\mathrm{G}} ; \mathrm{m}\right.$ w.e. $\left.\mathrm{a}^{-1}\right)$ is obtained from (Paterson, 1994)

$$
M_{\mathrm{G}}=P-B_{\mathrm{a}}-\mathrm{SB}
$$

where $P$ is precipitation $\left(\mathrm{ma}^{-1}\right), B_{\mathrm{a}}$ is the annual mass balance $\left(\mathrm{m}\right.$ w.e. $\left.\mathrm{a}^{-1}\right)$ and SB is the sublimation $\left(\mathrm{m}\right.$ w.e. $\left.\mathrm{a}^{-1}\right)$.

The discharge of the glacierized area, $D_{\mathrm{GA}}$, is obtained from the cumulated meltwaters from all the glaciers:

$$
D_{\mathrm{GA}}=M_{\mathrm{G}} S_{\mathrm{GA}}
$$

where $S_{\mathrm{GA}}$ is the overall surface area $\left(\mathrm{m}^{2}\right)$ of all the glaciers located in the catchment area averaged over the study period.

On the other hand, discharge from the ice-free area, $D_{\text {FOIA, }}$ can be obtained from

$$
D_{\mathrm{FOIA}}=C_{\mathrm{e}} P S_{\mathrm{FOIA}}
$$

where $C_{\mathrm{e}}$ is the runoff coefficient, $P$ is precipitation $\left(\mathrm{m} \mathrm{a}^{-1}\right)$ and $S_{\mathrm{FOIA}}$ is the surface area $\left(\mathrm{m}^{2}\right)$ of the ice-free area.

To solve these equations, the terms $B_{\mathrm{a}}, P, \mathrm{SB}, S_{\mathrm{GA}}, S_{\mathrm{FOIA}}$ and $C_{\mathrm{e}}$ need to be estimated. The 1975 Bolivian glacier inventory recorded 1826 glaciers in the Cordillera Real (Jordan, 1991). As mentioned above, only three glaciers have been monitored in Bolivia since 1991 using the traditional glaciological method (Rabatel and others, 2013). Mass-balance series over the tropical Andes are sparse, discontinuous and cover short time periods (Rabatel and others, 2013). To estimate the mass balances of the 70 glaciers located in the drainage basins of La Paz city, we used a relationship established by a linear multiple regression analysis with mass balance as the dependent variable, and altitude and exposure as independent predictors (Soruco and others, 2009a). This relationship was established on the basis of the analysis of DEMs of 21 glaciers over the Cordillera Real using digital photogrammetry on aerial photographs of 1956, 1963, 1975, 1983, 1997 and 2006. Soruco and others (2009a) showed that the mean altitude and exposure of a glacier explains a significant amount of its glacier-wide mass balance $\left(r^{2}=0.88\right)$ over the 1963-2006 period. According to this relationship, the mean annual mass balance ( $\mathrm{m}$ w.e. $\mathrm{a}^{-1}$ ) of each glacier averaged over the 1963-2006 period is expressed as a function of its mean altitude $Z$ (m a.s.l.) and exposure $E\left(^{\circ}\right)$ :

$$
B_{\mathrm{n}}=0.0011 Z-0.2584 \sin (E+135)-6.16
$$

Discharge measurements for each catchment area are only available between 2000 and 2007. These daily measurements were made at the outlet of the dams located in each catchment, by the private company Aguas del Illimani (today the La Paz city water resources are controlled by the public company EPSAS (Empresa Pública Social del Agua y Saneamiento S.A.)).

Long-term meteorological data around the drainage basin are sparse, and only available from three weather stations: San Calixto (3600 m a.s.I., since 1891), El Alto (4000 m a.s.I., since 1943) and P4750 (a pluviometer located at $4750 \mathrm{~m}$ a.s.I. near Glaciar Zongo, since 1971). The average annual precipitation measured at San Calixto $\left(P_{\mathrm{SC}}\right)$ and $\mathrm{El}$ Alto $\left(P_{\mathrm{EA}}\right)$ weather stations was 0.584 and $0.611 \mathrm{~m} \mathrm{a}^{-1}$ respectively for the period 1963-2006. The average annual precipitation measured by $\mathrm{P} 4750$ was $0.858 \mathrm{~m} \mathrm{a}^{-1}$ for the period 1971-2007. The average difference in the annual precipitation amount between San Calixto-El Alto weather stations and P4750 is 30\%. However, P4750 is located on the Amazonian side of the Cordillera Real, whereas San Calixto and El Alto stations, like our study catchments, are located on the Altiplano side, which is drier. In addition, according to Sicart and others (2007), there is no correlation between precipitation and elevation on Glaciar Zongo (4900-6100 ma.s.l.). Over glaciers located above $5000 \mathrm{~m}$ a.s.l., the precipitation term is assumed to be solid. This assumption is supported by measurements made at an automatic weather station (AWS) on Glaciar Zongo as part of the GLACIOCLIM program and surface energy-balance studies showing that precipitation over the glacier surface is almost entirely solid (e.g. Sicart and others, 2005).

The glacier sublimation term (SB) was estimated using monthly values of US National Centers for Environmental Prediction (NCEP)-US National Center for Atmospheric Research (NCAR) reanalysis data at $500 \mathrm{hPa}(\sim 5500 \mathrm{~m}$ a.s.l.) (Kalnay and others, 1996; Kistler and others, 2001) from the gridcell including the study area and an empirical relationship (Favier and others, 2008) given by $\mathrm{SB}=$ $\alpha\left(q-q_{\mathrm{s}}\right) v\left(\mathrm{~m}\right.$ w.e. month $\left.{ }^{-1}\right)$ where $q, q_{\mathrm{s}}$ and $v$ are reanalyzed NCEP-NCAR data for air specific humidity $\left(\mathrm{g} \mathrm{kg}^{-1}\right)$, saturated specific humidity $\left(\mathrm{g} \mathrm{kg}^{-1}\right)$ and horizontal wind speed $\left(\mathrm{m} \mathrm{s}^{-1}\right)$ respectively, and $\alpha$ is a coefficient for homogeneity of the empirical relationship (Favier and others, 2008). This coefficient, set at 0.694, was calibrated from monthly sublimation data measured at AWSs located on Glaciar Zongo, by Wagnon and others (2001) from September 1996 to August 1998 and by Sicart (2002) from September 1999 to August 2000. We used a constant annual sublimation value over the period 1963-2006 for the 70 glaciers computed from the above-described relationship: $\overline{\mathrm{SB}}=-0.170 \mathrm{~m} \mathrm{a}^{-1}$.

The surface area of the glaciers in the glacierized area was obtained from photogrammetric measurements using aerial photographs taken in 1975 and 2006 (Jordan, 1991; Soruco and others, 2009a). From photogrammetric measurements performed on 21 glaciers located within and around the study area, Soruco (2008) showed that reduction in the surface area of the glaciers was very limited ( $\sim 4 \%$ ) during the 1963-75 period. The ice-free surface area of each catchment was computed from National Chart SE19-03 $(1: 250000)$ of the Geographic Military Institute (IGM), Bolivia.

Finally, the runoff coefficient, $C_{\mathrm{e}}$, for the ice-free area was set at 0.56 according to Ramírez and others (2007). This coefficient was obtained from different theoretical coefficients according to different soil types in the Tuni-Condoriri catchment area. Since no measurements of the runoff coefficient were available for the other areas, we used the same value for all the catchment areas. 


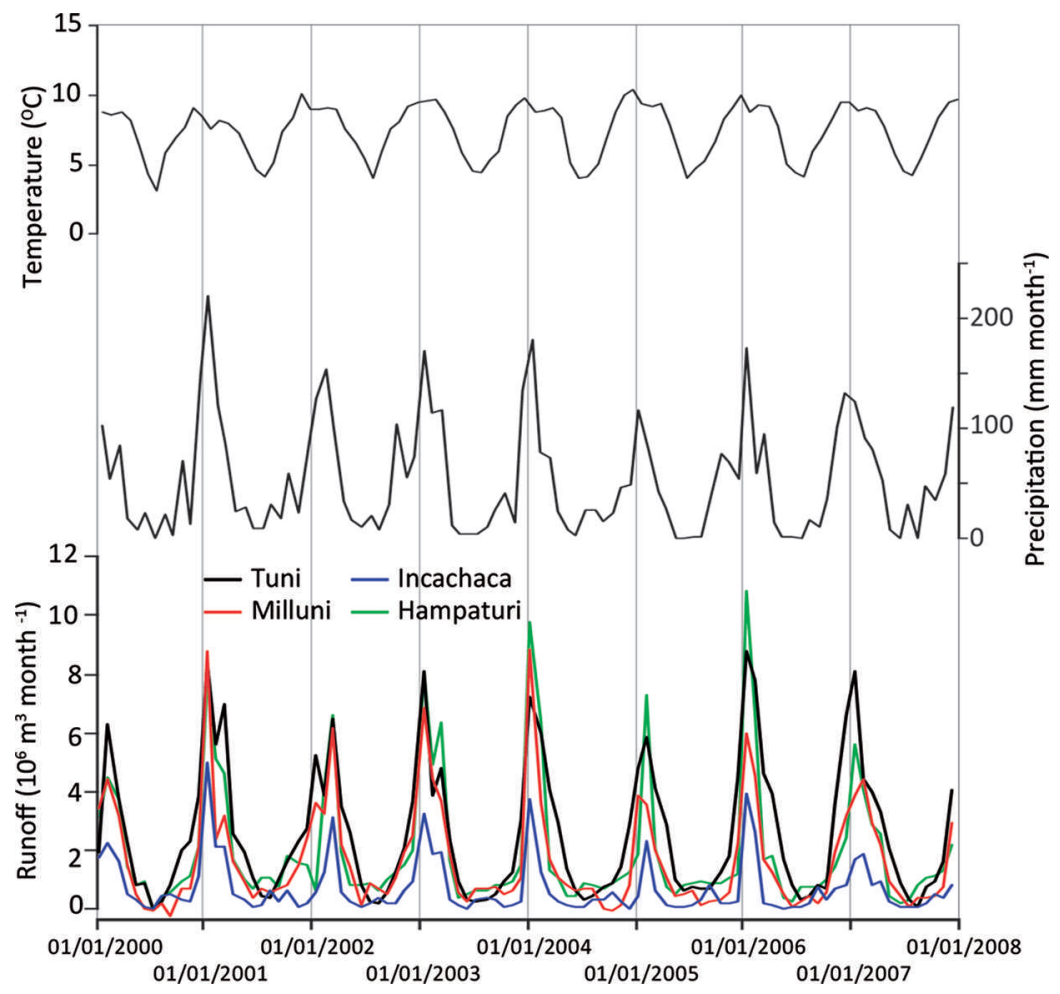

Fig. 2. Monthly runoff from La Paz drainage basins, monthly mean precipitation measured at San Calixto and El Alto weather stations and monthly mean temperature measured at El Alto station over the period 2000-07.

To validate our results, we compared the calculated with the measured total discharge for each catchment area. As mentioned above, discharge measurements were only available between 2000 and 2007 (Ramírez and others, 2007). Figure 2 shows the discharge measurements available for each catchment, the mean precipitation measured at San Calixto and El Alto weather stations and the mean temperature measured at El Alto weather station for the 2000-07 period. During the same period, the surface area of the glaciers was only measured once, in 2006. However, given that the impact of changes in area between 2000 and 2006 is small compared to other uncertainties, the comparison between calculated and measured discharges in the different drainage basins is appropriate. This point is discussed further below. Given that Eqn (4) was only calibrated for the 1963-2006 period, the glacier mass balances needed to be corrected to match the discharge measurement period. To this end, we used the geodetic mass-balance data obtained from digital photogrammetry for the 1997-2006 period (i.e. the average annual mass balance over the 10 years) for ten glaciers located in the La Paz-El Alto drainage basins (Soruco, 2008). From these data, we obtained a difference of $-0.5 \mathrm{mw}^{-e} \mathrm{a}^{-1}$ in the average annual mass balance of these glaciers between 1963-2006 and 1997-2006. This difference was used to infer the 1997-2006 average annual mass balance from the 1963-2006 average annual mass balance for all the other glaciers in the drainage area.

The monthly hydrological mass balance of nearby Glaciar Zongo was used to assess the seasonal (wet and dry seasons) contribution of all glaciers to the La Paz water system. The Glaciar Zongo hydrological series is available from 1973 to 2006. This is the longest mass-balance series in South America and has been validated using the geodetic method. The difference found between these two independent methods (i.e. hydrological and geodetic methods) was $0.55 \mathrm{mw}$.e. for the cumulative mass balance over the 1975-2006 period (Soruco and others, 2009b), which is a very small discrepancy $\left(<0.02 \mathrm{mw}\right.$.e. $\left.\mathrm{a}^{-1}\right)$. The average contribution of each month of the hydrological year to annual melt was computed using this time series and showed that glacier melt during the wet (dry) season represents $66 \%$ $(34 \%)$ of total annual melt. This relative seasonal contribution to annual melt is primarily driven by climate conditions and can be considered similar for all the glaciers in the study region. Regarding sublimation, the wet (dry) season represents $27 \%$ (73\%) of total annual sublimation. Regarding precipitation, the wet (dry) season represents 84\% $(16 \%)$ of the total annual amount. As we knew their seasonal contributions, we were able to transform the annual mass balance, the annual sublimation and the annual precipitation terms to seasonal terms, thereby enabling estimation of the glacier's contribution at a seasonal scale.

\section{RESULTS AND DISCUSSION}

\subsection{Water production from catchment areas for the periods 1963-2006 and 1997-2006}

Table 1 lists the calculated discharge at different periods for the four catchment areas that supply water to La Paz city. The comparison between calculated and measured total discharges over the four catchment areas shows that the main differences are in the Milluni and Incachaca catchment areas. However, when the cumulative total discharge measured over the 2000-07 period was compared with that calculated for the entire period (1963-2006) and for the shorter 1997-2006 period, the difference was only $2.9 \%$ and $3.4 \%$, respectively. From these results, and assuming that uncertainties on each term of our estimate (Section 4.2) do 
Table 1. Left: the data used for each catchment area in terms of mass balance, surface glacierized and ice-free areas. Centre: the results obtained in this study for each catchment area in terms of mean annual discharge over the periods 1963-2006 and 1997-2006, for the glacierized, ice-free and entire catchment areas. Right: comparison between calculated (1963-2006 and 1997-2006) and measured (2000-07) discharges

\begin{tabular}{|c|c|c|c|c|c|c|c|c|c|c|c|c|c|c|c|c|}
\hline \multirow[t]{4}{*}{ Catchment area } & \multicolumn{2}{|c|}{$\begin{array}{l}\text { Mass balance } \\
\qquad\left(B_{\mathrm{n}}\right)\end{array}$} & \multicolumn{2}{|c|}{$\begin{array}{c}\text { Surface } \\
\text { glacierized area } \\
\left(S_{\mathrm{GA}}\right)\end{array}$} & \multicolumn{2}{|c|}{$\begin{array}{l}\text { Surface ice-free } \\
\text { area }\left(S_{\text {FOIA }}\right)\end{array}$} & \multicolumn{2}{|c|}{$\begin{array}{c}\text { Discharge } \\
\text { glacierized area } \\
\left(D_{\mathrm{GA}}\right)\end{array}$} & \multicolumn{2}{|c|}{$\begin{array}{c}\text { Discharge } \\
\text { ice-free area } \\
\left(D_{\text {FOIA }}\right)\end{array}$} & \multicolumn{3}{|c|}{$\begin{array}{c}\text { Discharge catchment } \\
\text { areas }\left(D_{\mathrm{CA}}\right)\end{array}$} & \multicolumn{3}{|c|}{$\begin{array}{c}\text { Difference in discharge } \\
\text { catchment areas }\end{array}$} \\
\hline & $\begin{array}{l}1963- \\
2006\end{array}$ & $\begin{array}{l}1997- \\
2006\end{array}$ & $\begin{array}{l}1963- \\
2006\end{array}$ & $\begin{array}{l}1997- \\
2006\end{array}$ & $\begin{array}{l}1963- \\
2006\end{array}$ & $\begin{array}{l}1997- \\
2006\end{array}$ & $\begin{array}{l}1963- \\
2006\end{array}$ & $\begin{array}{l}1997- \\
2006\end{array}$ & $\begin{array}{c}1963- \\
2006\end{array}$ & $\begin{array}{l}1997- \\
2006\end{array}$ & $\begin{array}{l}1963- \\
2006\end{array}$ & $\begin{array}{l}1997- \\
2006\end{array}$ & $\begin{array}{c}2000- \\
2007\end{array}$ & $\begin{array}{l}1963- \\
2006\end{array}$ & $\begin{array}{l}1963- \\
2006\end{array}$ & $\begin{array}{l}1997- \\
2006\end{array}$ \\
\hline & & & & & & & & & & & & & & $\begin{array}{l}1997- \\
2006\end{array}$ & $\begin{array}{c}2000- \\
07\end{array}$ & $\begin{array}{c}2000- \\
07\end{array}$ \\
\hline & \multicolumn{2}{|c|}{$\mathrm{ma}^{-1}$} & \multicolumn{2}{|c|}{$\mathrm{km}^{2}$} & \multicolumn{2}{|c|}{$\mathrm{km}^{2}$} & \multicolumn{2}{|c|}{$10^{6} \mathrm{~m}^{3} \mathrm{a}^{-1}$} & \multicolumn{2}{|c|}{$10^{6} \mathrm{~m}^{3} \mathrm{a}^{-1}$} & \multicolumn{3}{|c|}{$10^{6} \mathrm{~m}^{3} \mathrm{a}^{-1}$} & \multicolumn{3}{|c|}{$\%$} \\
\hline Tuni-Condoriri & -0.59 & -1.09 & 7.04 & 4.58 & 70.47 & 72.92 & 7.2 & 6.9 & 23.7 & 24.5 & 30.9 & 31.4 & 30.5 & -1.6 & 1.3 & 2.9 \\
\hline Milluni & -0.43 & -0.93 & 2.51 & 1.31 & 68.49 & 69.69 & 2.1 & 1.7 & 23 & 23.4 & 25.1 & 25.1 & 20 & 0 & 22.6 & 22.6 \\
\hline Hampaturi & -0.68 & -1.2 & 2.47 & 1.56 & 57.03 & 57.94 & 2.8 & 2.5 & 19.2 & 19.5 & 22 & 22 & 23.9 & 0 & -8.3 & -8.3 \\
\hline \multirow[t]{2}{*}{ Incachaca } & -0.60 & -1.1 & 1.42 & 0.89 & 16.54 & 17.06 & 1.6 & 1.5 & 5.6 & 5.7 & 7.2 & 7.2 & 8.4 & 0 & -15.4 & -15.4 \\
\hline & & & & & & & & & \multicolumn{2}{|c|}{ Total discharge } & 85.2 & 85.7 & 82.8 & -0.6 & 2.9 & 3.4 \\
\hline
\end{tabular}

not compensate for each other, we conclude that (1) discharge has been fairly stable since 1963-2007, and (2) our assessment captures the main components of the water discharge. The uncertainty on each term is discussed in Section 4.2

Table 1 shows very small differences in discharge between the whole period (1963-2006) and 1997-2006. The average annual mass balance was more negative and the surface area of the glaciers decreased considerably over the recent period, but the two effects tended to balance out. The glacierized area reduction tended to decrease glacier runoff, whereas the glacier melt increase tended to increase runoff. This suggests that, on average, these glaciers have not yet reached the threshold beyond which the impact of the surface area reduction will predominate (Baraer and others, 2012). The most significant difference would be expected in the Tuni-Condoriri catchment area (Table 1), because TuniCondoriri had the greatest glacierized area of the catchments studied here. Based on the analysis of 376 glaciers, Soruco and others (2009a) concluded that the surface area of glaciers over the Cordillera Real decreased by $\sim 50 \%$ between 1975 and 2006. However, changes in runoff were minor (the difference in total discharge of the four catchment areas was $-0.6 \%$ ), evidence that the glaciers are still maintaining runoff due to higher melt rates per surface area.

It is worth emphasizing that at annual and seasonal timescales, the results obtained by Baraer and others (2012) in the Peruvian Cordillera Blanca are similar to those obtained in the present study for the La Paz region. To analyze the contribution of glaciers to the hydrological regime, Baraer and others (2012) used time series of daily discharge measured over the period 1953-2009 at nine measurement points located in the Cordillera Blanca, a region whose precipitation regime resembles that observed in the Bolivian Andes. However, their results showed that the glacier retreat in some of the watersheds in the Cordillera Blanca also resulted in a decrease in annual discharge, with a more pronounced decrease during the dry season. Baraer and others (2012) concluded that the water peak had been crossed in these catchments, which, in 2006, was not the case in the La Paz drainage areas studied here.

\subsection{Uncertainties and sensitivity to model parameters}

The main source of uncertainty in the discharge assessment is the assumed constant precipitation and a constant runoff coefficient for each catchment area. Precipitation and the runoff coefficient control the majority of water produced in the catchment areas $(91-96 \%$ of the surface area of each catchment in 1963 was ice-free). Sensitivity experiments were carried out for these two variables. On the one hand, results revealed that a $10 \%$ change in the runoff coefficient leads to a change in water production from the ice-free area of $\sim 1 \%$ on average, for the four catchment areas concerned. We conclude that the sensitivity of the runoff coefficient for the ice-free area is low. On the other hand, a 10-30\% change in precipitation leads to an average change in water production from the ice-free area and glacierized area of about $10-30 \%$ and $6.5-17.8 \%$, respectively, for the four catchment areas. Thus, a change in precipitation amount results in changes of similar proportions in the production of water from the ice-free areas. In the glacierized areas, the sensitivity of water production to precipitation (6.5-17.8\%) remains low in absolute terms, due to the low percentage of glacier coverage in each catchment area (12-5\%).

The uncertainty due to the sublimation term is low because the glacierized areas are small compared to the icefree areas. The uncertainty of this parameter is difficult to assess; for Glaciar Zongo, it was assumed to be $<0.1 \mathrm{~m} \mathrm{w.e}^{-1}$ (Soruco and others, 2009b).

Given that the exact size of the areas was obtained from precise photogrammetric data, the uncertainty on the glacierized and ice-free areas is $<5 \%$ (Soruco and others, 2009a). The uncertainty on the mass balance was assessed based on the standard deviation in Soruco and others (2009a) from the fit of Eqn (4) on the mass balances of the 21 glaciers, yielding $0.5 \mathrm{mw}^{-e \mathrm{a}^{-1}}$ (Soruco, 2008), and leading to an average uncertainty of $12 \%$ on the total discharge, which equaled $85 \times 10^{6} \mathrm{~m}^{3} \mathrm{a}^{-1}$.

To compute the year-to-year contribution of glaciers, instead of computing an average annual contribution over a given time period (as we did), the annual mass-balance variation of each glacier must be known. For the Bolivian 

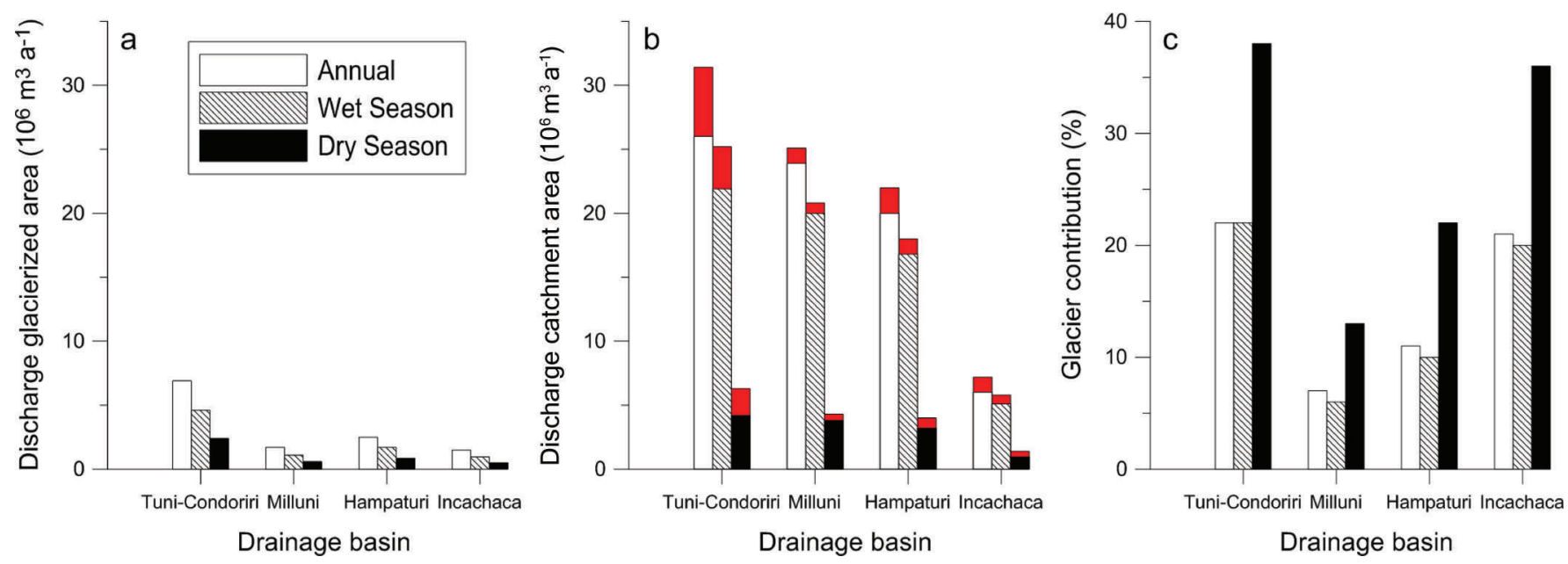

Fig. 3. $(a, b)$ Annual and seasonal mean discharges from each of the catchment areas to La Paz city over the 1997-2006 period (a) from the glacierized areas and (b) from entire catchment areas. The red portions in (b) represent the potential loss in discharge in the case of complete disappearance of all the glaciers. (c) Annual and seasonal contribution of the discharge from the glacierized areas to the total discharge.

Cordillera Real, the only available long-term annual massbalance data series is for Glaciar Zongo and starts in 1975 (Soruco and others, 2009b).

However, Glaciar Zongo $\left(\sim 1.8 \mathrm{~km}^{2}\right)$ is a relatively large glacier in the Cordillera Real, compared to the others in the studied catchment (average glacier surface area in 1963 was $0.26 \mathrm{~km}^{2}$ ). Rabatel and others (2013) showed that, in recent decades, tropical glaciers in South America located at low altitudes $(<5400$ ma.s.l.) have lost about twice as much mass as glaciers located at high altitudes (>5400 ma.s.l.). Thus, interannual variations in the Glaciar Zongo mass balance cannot be directly extrapolated to the other glaciers in the catchments studied here, because local effects due to the reduced size of these glaciers are stronger than the regional climate effect (Soruco and others, 2009a; Rabatel and others, 2013).

\subsection{Seasonal glacier contribution to La Paz city water resources}

The glaciers' contribution to the water resources of La Paz city at annual and seasonal timescales is shown in Figure 3. At an annual scale and considering the four catchment areas together, the glaciers' contribution reaches 15\%. At seasonal scale, their contribution is $14 \%$ in the wet season and $27 \%$ in the dry season. Note that the discharge from the glacierized areas during the dry season $\left(4.3 \times 10^{6} \mathrm{~m}^{3} \mathrm{a}^{-1}\right)$ accounts for only half of the discharge during the wet season $\left(8.4 \times 10^{6} \mathrm{~m}^{3} \mathrm{a}^{-1}\right)$. This effect is typical for tropical glaciers, whose ablation rates are high during the wet season, concomitant with the higher accumulation amount. However, it should also be noted that $15 \%$ of water supplied at an annual timescale is the result of glacier melt, so the glaciers' contribution cannot be disregarded.

Finally, we estimated the water loss for La Paz city according to a scenario in which the glaciers completely disappear considering $S_{\mathrm{GA}}=0 \%$ and $S_{\mathrm{FOIA}}=100 \%$, with no change in precipitation. Even if snow can fall at high altitudes, at annual timescales, this does not represent water storage as the snow generally melts within a few days (i.e. neither seasonal nor perennial snow cover is observed outside the glaciers). According to this scenario, the water production of the four catchment areas would undergo an annual decrease of $12 \%, 9 \%$ in the wet season and $24 \%$ in the dry season. The uncertainty on total discharge is $3.4 \%$; however, the uncertainty in each individual catchment ranges from $3 \%$ to $23 \%$. The most affected catchment basins would be Tuni-Condoriri (17\% at annual scale, $13 \%$ in the wet season and $33 \%$ in the dry season) and Incachaca (17\% at annual scale, $12 \%$ in the wet season and $31 \%$ in the dry season) due to their large glacierized area. Due to the geographical location of the water purification stations, the northern and southern sides of the city would be most affected by the drop in water production.

\section{CONCLUSIONS}

This is the first time the contribution of glaciers to the water resources of La Paz city has been estimated. This estimate was made by assessing the average annual mass balance of 70 glaciers located within the four drainage basins of La Paz city. Average values of precipitation, sublimation and runoff coefficients were assumed to drive the discharge produced by the ice-free and the glacierized areas. The assumption of constant precipitation (in time and space) leads to the main uncertainty in the assessment of the discharge produced by the ice-free areas, and, to a lesser extent, of the discharge produced by the glacierized areas. Uncertainty in the assessment of discharge due to the other parameters remains low. The comparison of calculated and measured average discharge for the four catchment areas for the period 200007 revealed a difference of only $3.4 \%$, thus confirming that our assessment captured the main contributions to the discharge despite the assumption that the parameters remained constant. We conclude that glaciers contributed $15 \%$ of the water resources of La Paz city at an annual timescale over the entire study period. At a seasonal timescale, the most significant influence of the glaciers occurs in the dry season, when the glacier contribution to total discharge reaches $27 \%$, ranging from $13 \%$ to $38 \%$ depending on the percentage of glacial coverage of the catchment concerned. Regardless of the marked downward trend of glacier extent in the region in recent decades, the difference in water production in the four catchment areas between the periods 1963-2006 and 1997-2006 was only $-0.6 \%$, confirming that glacier melt continues to maintain runoff. We conclude that, at least until 2006, the loss in 
glacier surface area was compensated for by the increasingly negative glacier mass balance. In the future, in the case of the complete disappearance of glaciers and assuming no change in precipitation, total water production for La Paz city will decrease by $12 \%$ at an annual scale and by $24 \%$ during the dry season.

To increase our knowledge of the hydro-glaciological functioning of these Bolivian watersheds, two main tasks are recommended for future research. First, the need for better understanding of the precipitation regime must be addressed with an increase of in situ data, validation of satellite products (e.g. Tropical Rainfall Measuring Mission (TRMM)) and with the use of data generated by regional downscaled models that will help grasp the spatial and temporal variability of this key variable. Second, an integrated spatially distributed hydrologic and glacier dynamic model as described by Naz and others (2014) and Réveillet and others (2015) could be a good way to quantify the effect of the glacier recession on variations in streamflow and to predict future water resources in this Andean region.

\section{ACKNOWLEDGEMENTS}

This study was conducted as part of the GLACIOCLIM observatory (http://www-Igge.ujf-grenoble.fr/ServiceObs/ SiteWebAndes/index.htm) and the LMI GREAT-ICE supported by the French Institut de Recherche pour le Développement (IRD). We are grateful for the assistance of IGEMA Institute (Instituto de Investigaciones Geológicas y del Medio Ambiente) and $\mathrm{IHH}$ Institute (Instituto de Hidráulica e Hidrología) of the Universidad Mayor de San Andrés (UMSA), La Paz. Contributing authors from LGGE and LTHE acknowledge the contribution of LabEx OSUG@2020 (Investissements d'avenir - ANR10LABX56). We acknowledge Shin Sugiyama (Scientific Editor) and two anonymous reviewers for constructive comments which helped us improve the paper.

\section{REFERENCES}

Baraer M and 8 others (2012) Glacier recession and water resources in Peru's Cordillera Blanca. J. Glaciol., 58(207), 134-150 (doi: 10.3189/2012JoG11J186)

Bradley RS, Vuille M, Diaz H and Vergara W (2006) Threats to water supplies in the tropical Andes. Science, 312(5781), 1755-1756 (doi: 10.1126/science.1128087)

Buytaert W and De Bièvre B (2012) Water for cities: the impact of climate change and demographic growth in the tropical Andes. Water Resour. Res., 48, W08503 (doi: 10.1029/ 2011WR011755)

Coudrain A, Francou B and Kundzewicz ZW (2005) Glacier shrinkage in the Andes and consequences for water resources. Hydrol. Sci. J., 50(6), 925-932 (doi: 10.1623/hysj.2005.50.6.925)

Favier $\mathrm{V}$ and 8 others (2008) Evidence of groundwater flow on Antizana ice-covered volcano, Ecuador. Hydrol. Sci. J., 53(1), 278-291 (doi: 10.1623/hysj. 53.1.278)

Francou B, Ribstein P, Saravia R and Tiriau E (1995) Monthly balance and water discharge of an inter-tropical glacier: Zongo Glacier, Cordillera Real, Bolivia, $16^{\circ}$ S. J. Glaciol., 41(137), 61-67

Francou B, Ramírez E, Caceres B and Mendoza J (2000) Glacier evolution in the tropical Andes during the last decades of the 20th century: Chacaltaya, Bolivia and Antizana, Ecuador. Ambio, 29(7), 416-422

Gascoin S, Kinnard C, Ponce R, Lhermitte S, MacDonell S and Rabatel A (2011) Glacier contribution to streamflow in two headwaters of the Huasco River, Dry Andes of Chile. Cryosphere, 5(4), 1099-1113 (doi: 10.5194/tc-5-1099-2011)

Jordan E (1991) Die Gletscher der Bolivianischen Anden. Franz Steiner Verlag, Stuttgart

Kalnay E and 21 others (1996) The NCEP/NCAR 40-Year Reanalysis Project. Bull. Am. Meteorol. Soc., 77(3), 437-471

Kinouchi T, Liu T, Mendoza J and Asaoka Y (2013) Modeling glacier melt and runoff in a high-altitude headwater catchment in the Cordillera Real, Andes. Hydrol. Earth Syst. Sci., 10, 13 093-13 144 (doi: 10.5194/hessd-10-13903-2013)

Kistler R and 12 others (2001) The NCEP-NCAR 50-Year Reanalysis: monthly means CD-ROM and documentation. Bull. Am. Meteorol. Soc., 82(2), 247-267

Liu T, Kinouchi T and Ledezma F (2013) Characterization of recent glacier decline in the Cordillera Real by LANDSAT, ALOS and ASTER data. Remote Sens. Environ., 137, 158-172

Mark BG and Seltzer GO (2003) Tropical glacier meltwater contribution to stream discharge: a case study in the Cordillera Blanca, Peru. J. Glaciol., 49(165), 271-281

Naz BS, Frans CD, Clarke GKC, Burns P and DP Lettenmaier (2014) Modeling the effect of glacier recession on streamflow response using a coupled glacio-hydrological model. Hydrol. Earth Syst. Sci., 18, 787-802 (doi:10.5194/hess-18-787-2014)

Paterson WSB (1994) The physics of glaciers, 3rd edn. Pergamon Press, Oxford

Rabatel A, Machaca A, Francou B and Jomelli V (2006) Glacier recession on the Cerro Charquini (Bolivia $16^{\circ} \mathrm{S}$ ) since the maximum of the Little Ice Age (17th century). J. Glaciol., 52(176), 110-118 (doi: 10.3189/172756506781828917)

Rabatel A and 7 others (2012) Can the snowline be used as an indicator of the equilibrium line and mass balance for glaciers in the outer tropics? J. Glaciol., 58(212), 1027-1036 (doi: 10.3189/ 2012JoG12J027)

Rabatel A and 27 others (2013) Current state of glaciers in the tropical Andes: a multi-century perspective on glacier evolution and climate change. Cryosphere, 7(1), 81-102 (doi: 10.5194/ tc-7-81-2013)

Ramírez E and 9 others (2007) Deshielo de la cuenca del Tuni Condoriri y su impacto sobre los recursos hidricos de las ciudades de La Paz y El alto. (Financiamiento Paises Bajos - Plan Quinquenal PNCC) Programa Nacional de Cambios Climáticos, La Paz

Rangecroft S, Harrison S, Anderson J, Magrath A, Castel P and Pacheco P (2013) Climate change and water resources in arid mountains: an example from the Bolivian Andes. Ambio, 42(7), 852-863

Réveillet M., Rabatel A, Gillet-Chaulet F and Soruco A (2015) Simulations of changes in Glaciar Zongo, Bolivia $\left(16^{\circ} \mathrm{S}\right)$, over the 21 st century using a 3-D full-Stokes model and CMIP5 climate projections. Ann. Glaciol., 56(70) (see paper in this issue) (doi: 10.3189/2015AoG70A113)

Ribstein P, Tiriau E, Francou B and Saravia R (1995) Tropical climate and glacier hydrology: a case study in Bolivia. J. Hydrol., 165(14), 221-234 (doi: 10.3189/002214308784886063)

Sicart JE (2002) Contribution à l'étude des flux d'energie, du bilan de masse et du debit de fonte d'un glacier tropical: le Zongo, Bolivie. (PhD thesis, Université Paris VI)

Sicart JE, Wagnon $\mathrm{P}$ and Ribstein $\mathrm{P}$ (2005) Atmospheric controls of the heat balance of Zongo Glacier (16 ${ }^{\circ} \mathrm{S}$, Bolivia). J. Geophys. Res., 110(D12), D12106 (doi: 10.1029/2004JD005732)

Sicart JE, Ribstein P, Francou B, Pouyaud B and Condom T (2007) Glacier mass balance of tropical Zongo glacier, Bolivia, comparing hydrological and glaciological methods. Glob. Planet. Change, 59, 27-36 (doi: 10.1016/j.gloplacha.2006.11.024)

Soruco A (2008) Etude du retrait des glaciers depuis cinquante ans dans les bassins hydrologiques alimentant en eau la ville de La Paz - Bolivie $\left(16^{\circ} \mathrm{S}\right)$. (PhD thesis, Université Joseph Fourier Grenoble I)

Soruco A, Vincent C, Francou B and Gonzalez JF (2009a) Glacier decline between 1963 and 2006 in the Cordillera Real, 
Bolivia. Geophys. Res. Lett., 36(3), L03502 (doi: 10.1029/ 2008GL036238)

Soruco A and 9 others (2009b) Mass balance of Glaciar Zongo, Bolivia, between 1956 and 2006, using glaciological, hydrological and geodetic methods. Ann. Glaciol., 50(50), 1-8 (doi: 10.3189/172756409787769799)

Stocker TF and 9 others eds (2013) Climate change 2013: the physical science basis. Contribution of Working Group I to the Fourth Assessment Report of the Intergovernmental Panel on Climate Change. Cambridge University Press, Cambridge

Thibert E and C Vincent (2009) Best possible estimation of mass balance combining glaciological and geodetic methods. Ann. Glaciol., 50, 112-118 (doi: 10.3189/172756409787769546)
Vergara W and 7 others (2007) Economic impacts of rapid glacier retreat in the Andes. Eos, 88(25), 261-264

Wagnon P, Ribstein P, Francou B and Pouyaud B (1999) Annual cycle of energy balance of Zongo Glacier, Cordillera Real, Bolivia. J. Geophys. Res., 104(D4), 3907-3923 (doi: 10.1029/ 1998JD200011)

Wagnon P, Ribstein P, Francou B and Sicart JE (2001) Anomalous heat and mass budget of Glaciar Zongo, Bolivia, during the 1997/98 El Niño year. J. Glaciol., 47(156), 21-28 (doi: 10.3189/ 172756501781832593)

Zemp M and 16 others (2013) Reanalysing glacier mass balance measurement series. Cryosphere, 7, 1227-1245 (doi: 10.5194/ tc-7-1227-2013) 